\title{
Criterios \\ Adquisiciones para las colecciones de los museos: deontología y propiedad intelectual
}

Pablo Hereza Lebrón

Conservador de museos

\section{Resumen}

Las adquisiciones para las colecciones de museos constituyen una de las funciones sociales encomendadas a los museos para una interpretación cultural que ayude al ciudadano a identificarse con su Patrimonio Cultural y a comprender y respetar el ajeno.

Función social que debe desarrollarse mediante una deontologia profesional que autorregule las actuaciones del museo y las Administraciones, y con la adopción y cumplimiento de la normativa de la propiedad intelectual, contribuyendo al respeto y defensa de los derechos de autor.
En los últimos años se viene observando una profusión de artículos y monográficos relativos a las adquisiciones para las colecciones de los museos. En la mayoría de ellos encontramos listados y estadisticas, justificaciones presupuestarias de la actividad coleccionista de la Administración o, en todo caso, aproximaciones históricas sobre las adquisiciones en determinados museos. En pocas ocasiones se observan otras aportaciones, y cuando se encuentran, sin duda ya se reflejan en el elevado nivel de calidad que estos profesionales imprimen al incremento de sus colecciones.

Abundan también cursos y seminarios, donde especialistas de diferentes ámbitos analizan las adquisiciones y su relación con el mercado del arte. El deslumbrante y glamuroso mundo, para algunos, de las antigüedades, galerias de arte y casas de subastas, oculta otros asuntos de interés para los profesionales de los museos que, sin ser nuevos, no son tratados.

Y como última tendencia museística, también son numerosos los planes directores, estratégicos, de desarrollo, de marketing, de calidad, etc., voluntariosos recordatorios del ejercicio coherente de la profesión museística, pero que olvidan que las adquisiciones para las colecciones museográficas deben tratarse como un objetivo primordial en estos instrumentos de planificación, cuestión siempre presente en los proyectos museológicos.

Pero las adquisiciones para las colecciones de los museos son algo más que una estadística, historia, comercio o un olvido. Hay dos aspectos que creo fundamentales, aunque a veces hayan sido olvidados por su complejidad, que desearía abordar mediante mi perspectiva museológica. Me refiero a la adopción por parte de los profesionales de los museos y de las Administraciones competentes de unas normas deontológicas que rijan las adquisiciones, y que en éstas se respeten los derechos de propiedad intelectual.

\section{La deontología de las adquisiciones}

Ese tratado de deberes que es la deontología encuentra su primera plasmación en la Deontología de las adquisiciones, de 1970, que se engarzará en el Código de deontología del ICOM para los museos, aprobado por unanimidad en la $15^{\mathrm{a}}$ Asamblea General del ICOM que se celebró en Buenos Aires, Argentina, el 4 de noviembre de 1986 y modificado en la 20 asamblea General en Barcelona, España, el 6 de julio de 2001.Tras las revisiones del Comité de deontología del ICOM, se aprobó una nueva versión en la $21^{\text {a }}$ Asamblea General de ICOM que se celebró en Seúl, Corea, el 8 de octubre de 2004.

El Código establece unas normas mínimas de deontología de las instituciones museísticas y de conducta profesional en los museos, regulando el desempeño profesional en un ámbito tan controvertido como el de las adquisiciones para las colecciones de los museos. Además proyecta sobre la regulación jurídica del Patrimonio Histó- 
rico una mayor nitidez en aquellas partes menos definidas, como las adquisiciones, ya que la actual legislación estatal y autonómica no tratan más que procedimientos administrativos de adquisición, en vez de aportaciones de carácter técnico que permitan a los museos la formación y ordenación de sus colecciones.

Una de las principales necesidades de los museos y Administraciones responsables es la relativa a la definición de su política de adquisiciones, salvaguarda de los intereses del mercado del arte, de las presiones mediáticas o de los criterios más o menos científicos de los gestores. El anuncio de salida al mercado de una obra de autor reconocido desata un cúmulo de presiones, proporcionales al ámbito local y tamaño del mercado, muy dificiles de gestionar por los responsables de las instituciones. Es necesario contar con un documento de planificación de las adquisiciones, elaborado por el museo y consensuado con la Administración gestora, de carácter científico y museológico, lo suficientemente genérico para no desaprovechar las oportunidades del mercado, pero tan detallado como para poder argumentar una posición que pueda contradecir las presiones del entorno en un momento determinado.

La publicación periódica del documento, o su visualización a través de exposiciones monográficas de las obras adquiridas, servirán de piedra de toque para la revisión del mismo. Este documento debe elaborarse sin temor a desvelar al mercado las estrategias de la institución para sus adquisiciones, pues considero que las negociaciones deben producirse con una escrupulosa honradez con el ofertante, sin propósitos engañosos, aunque con el objetivo final de establecer el mejor justiprecio. Quizás, alguien opine que en las adquisiciones no debe primar el factor económico sobre el interés en conseguir determinado bien, sobre todo, cuando su excepcionalidad justifique los mayores esfuerzos.

El documento permitirá también la cooperación entre los museos para una política de adquisiciones, iniciando estrategias de colaboración cuando actúen varios museos en el mismo ámbito del mercado, y que puedan consensuar qué colección es prioritaria cuando pretendan un mismo bien, ya que los museos no deberían competir en el mercado. Esta cooperación evitará la rigidez que impone el artículo 38.4 de la Ley del Patrimonio Histórico Español que señala que el ejercicio de los derechos de tanteo y retracto por parte de la Administración del Estado tendrá carácter preferente siempre que se trate de adquirir bienes muebles para un museo [...] de titularidad estatal. La cuestión no es la titularidad del museo ni quien lo gestiona, sino la coherencia de las colecciones, tal y como alguna vez he defendido cuando han colisionado los intereses legítimos de diferentes instituciones.

La mencionada cooperación entre museos y Administraciones debe alcanzar su máximo grado cuando se trate de la recuperación de bienes de la Patrimonio Histórico que se encuentren fuera de España, ya que las adquisiciones no sólo acrecientan las colecciones museográficas de las instituciones, sino el propio Patrimonio Histórico Español.

La definición de una política de adquisiciones requiere la previa definición de una política de colecciones que aborde todas las cuestiones relativas a su conservación, investigación y difusión. En esta línea no quiero desaprovechar la ocasión de lamentar las oportunidades perdidas por los profesionales y las Administraciones competentes para la reordenación de los fondos museográficos mediante la revisión con criterios científicos de las colecciones estables y los depósitos. La pátina que la historia ha impreso sobre determinadas colecciones no justificaría su formación caprichosa y su falta de coherencia. Un reto que sólo podría ser abordado con el estricto cumplimiento de una deontología profesional que limitase los intereses personales o localistas de los profesionales, museos y Administraciones gestoras.

$\mathrm{Ni}$ los museos ni las Administraciones gestoras deben efectuar adquisiciones de objetos en situación ilícita. Cuando exista una minima duda, el profesional del museo debe rechazar la operación, y en su caso, denunciarla. Creo también que ningún motivo justificaría la adquisición de objetos de dudosa procedencia, aunque el propio Código de deontología ofrezca alguna alternativa de actuación para estas situaciones.

Entiendo, en la línea del Código de deontología, que los museos tienen mucho que decir sobre el estudio y acopio de objetos sobre el terreno; por ejemplo, sobre esa fuente inagotable de adquisiciones que es la excavación arqueológica. Los profesionales de los museos no deben resignarse al mero papel de receptor de estos bienes y exigir de la Administración que autoriza y de los arqueólogos un papel de corresponsabilidad en su gestión. El fin de cualquier adquisición no acaba en la transmisión o gestión de la propiedad, y por ello sólo se debería adquirir lo que se pueda conservar, investigar y difundir.

El museo debe tener una posición clara cuando se produzcan adquisiciones condicionales en forma de donaciones y legados. $\mathrm{Ni}$ la aceptación indiscriminada ni el simple rechazo, sino la clarificación y negociación de cualquier condición o interés. Siempre he defendido en mi ejercicio profesional las siguientes directrices para la aceptación de donaciones y legados:

$>$ Que la donación o el legado se efectúe sin condicionamiento de adscripción y depósito del bien a un museo determinado. Excepcionalmente, y para los bienes de especial interés, cuyo ofrecimiento se condicionase, se estudiarán las circunstancias especiales que concurriesen, y siempre que en el museo de adscripción existiesen suficientes medios personales y patrimoniales para hacer frente a su uso y conservación. En caso de aceptar la donación o el legado con el condicionamiento de un destino de terminado, se estará a lo dispuesto en la legislación vigente. 


\section{Criterios}

Adquisiciones para las

colecciones de los

museos: deontología y

propiedad intelectual

\section{Pablo Hereza Lebrón}

$>$ Que la donación o el legado se efectúe sin condicionamiento en la obligación de exposición del bien, y se estará a lo dispuesto en el programa museológico y museográfico que en cada momento esté previsto por el museo. En caso de aceptarse la donación con el condicionamiento de su exposición, se estará también a lo dispuesto en la legislación vigente.

$>$ Que el bien no se encuentre gravado y, si así fuera, se estará a lo dispuesto en la legislación vigente.

Si bien el profesional del museo no va estar afectado por conflictos de intereses, otros participantes en los procesos de adquisición sí pueden estarlo legítimamente. Así, en los últimos años se observa, entre los integrantes de los órganos de consulta y valoración de las Administraciones competentes, a profesionales como galeristas, coleccionistas y artistas, que pueden tener intereses legítimos en el mercado. De persistir en esta línea, se debería exigir el mismo cumplimiento del Código de deontología que al resto de los profesionales de los museos. Esta exigencia debería también alcanzar los niveles, directamente participantes, de la dirección de la política cultural.

En cualquier caso, y para todos los participantes en los procesos de adquisición, sería deseable la declaración responsable de la actividad coleccionista personal y su relación con el ámbito de actuación del museo, actividad compleja que podría confundirse en alguna ocasión con la prohibición de participar en el comercio de bienes del Patrimonio Cultural. La máxima exigencia profesional debería imperar en todo lo relativo a la autentificación, valoración o tasación de bienes, sin olvidar lo que la legislación vigente obligue a cada categoría de profesionales de los museos. En esta misma línea de los conflictos de intereses, no soy partidario de la exposición de bienes en proceso de adquisición, práctica usual en los últimos años en determinadas instituciones, y que puede interferir en la lógica negociadora. Cuestión distinta es el depósito del bien con objeto de su estudio y autentificación, con carácter previo a su adquisición.

\section{La propiedad intelectual y las adquisiciones}

Del deseable cumplimiento de unas normas de carácter ético pasamos al obligado cumplimiento de las normas que se plasman en el Real Decreto Legislativo 1/1996, de 12 de abril, por el que se aprueba el texto refundido de la Ley de propiedad intelectual, regularizando, aclarando y armonizando las disposiciones legales vigentes sobre la materia.

Hay que partir de la base, a veces olvidada o conscientemente ignorada, de que la propiedad intelectual de la obra artística corresponde al autor por el sólo hecho de su creación, y está integrada por unos derechos morales, que son irrenunciables e in- alienables, y por unos derechos de explotación (reproducción, distribución, comunicación pública y transformación) que pueden ser transmitidos a terceros. Todo esto es fundamental en los procesos de adquisición para las colecciones de museos, ya que por la adquisición de la propiedad del soporte material de la obra no se tiene ningún derecho de explotación sobre la misma. El problema radica cuando los museos y Administraciones gestoras pretenden adquirir el soporte material de la obra y sus correspondientes derechos de explotación. Así, es corriente la redacción de cláusulas en los contratos de adquisición, que son nulas o anulables, como esa tan usual y extendida de "Ios derechos de explotación que generen los bienes suministrados quedarán de propiedad exclusiva del adquirente".

Hasta aquí el problema planteado, que sigue sin comprenderse en diferentes ámbitos de los museos y de las Administraciones gestoras, de la normativa división entre la materialidad de la obra artística y los derechos morales y de explotación de la misma.

Los derechos de explotación pueden ser gestionados por el propio autor o cederlos a un tercero para su gestión, por ejemplo, las reconocidas por la Ley de propiedad intelectual, entidades de gestión de los derechos de propiedad intelectual. En la actualidad existen ocho entidades autorizadas por el Ministerio de Educación, Cultura y Deporte (ver cuadro adjunto): Sociedad General de Autores y Editores (SGAE); Centro Español de Derechos Reprográficos (CEDRO); Asociación de Gestión de Derechos Intelectuales (AGEDI); Artistas Intérpretes o Ejecutantes, Sociedad de Gestión de España (AIE); Visual, Entidad de Gestión de Artistas Plásticos (VEGAP); Entidad de Gestión de Derechos de los Productores Audiovisuales (EGEDA); Artistas Intérpretes, Sociedad de Gestión (AISGE) y Asociación Derechos de Autor de Medios Audiovisuales (DAMA).

Sin necesidad de posicionarse en el lado de los intereses legitimos de estas entidades, de otros terceros o de los propios autores, está claro que los profesionales de los museos tienen un reto ineludible, más allá de la queja continua por el coste ocasionado con las correspondientes tarifas de los derechos de explotación. Es necesario que los profesionales de los museos participen del debate teórico que las entidades de gestión promueven, pues tendrá su repercusión en las directivas sobre derechos de autor de la Unión Europea y en la normativa nacional. De la confluencia del interés público del museo y el interés privado del autor surge la aportación de los museos al deseable debate teórico.

Sin ánimo de ser exhaustivo, la Ley de propiedad intelectual actúa sobre las conocidas funciones de los museos de conservación, investigación, comunicación y exhibición de sus colecciones. Por ejemplo:

> Conservación. El artículo 14.4 reconoce que corresponde al autor el derecho moral de exigir el respeto a la integridad de la 
obra e impedir cualquier deformación, modificación, alteración o atentado contra ella que suponga perjuicio a sus legítimos intereses o menoscabo a su reputación.

$>$ Investigación. El artículo 37.1 señala que los titulares de los derechos de autor no podrán oponerse a las reproducciones de las obras, cuando aquellas se realicen sin finalidad lucrativa por los museos [...] y la reproducción se realice exclusivamente para fines de investigación.

> Comunicación y exhibición. El artículo 37.2 indica que los museos [...] no precisarán autorización de los titulares de los derechos ni les satisfarán remuneración por los préstamos que realicen, y el artículo 56.2 garantiza que el propietario del original de una obra de artes pláticas o de una obra fotográfica tendrá el derecho de exposición pública de la obra con los límites que se señalan.

En este debate no debe faltar un posicionamiento de carácter económico por parte de los profesionales de los museos. Es evidente, que hoy en día, los museos generan una industria cultural cada vez más importante. Algunos deberian justificar por qué en esta industria cultural el autor sólo debe participar en el momento de la venta de su obra. El museo también debería justificar si quiere convertirse en un participante más de esa industria cultural o ser exclusivamente el núcleo cultural para que otros desarrollen a su alrededor sus legítimas actividades económicas. Además, no creo que los museos o las Administraciones competentes puedan gestionar de manera eficiente los derechos de explotación legalmente cedidos, y si así lo hicieran se convertirian en una entidad de gestión más. Difícilmente los ingresos obtenidos amortizarian los gastos que para una Administración pública supondría una estructura organizativa de este tipo.

En cualquier caso, la capacidad del museo para generar recursos económicos no debe sustituir el ineludible compromiso público de una financiación que garantice suficientemente todas las funciones que el museo tiene encomendadas por la sociedad.

\section{Conclusión}

Las adquisiciones para las colecciones de museos constituyen una de las funciones sociales encomendadas a los profesionales de los museos para una interpretación cultural que ayude al ciudadano a identificarse con su Patrimonio Cultural y a comprender y respetar el ajeno. Función social que debe desarrollarse en el estricto cumplimiento de una deontología profesional y en el respeto a los derechos de autor.

Por ello, se debería adoptar, como declaración de intenciones, el Código de deontología y la Ley de propiedad intelectual en aque- llos documentos administrativos que regulen las adquisiciones para las colecciones de los museos (pliego de cláusulas administrativas particulares, contrato, etc.), en los documentos técnicos de los museos (cartas de servicios, planes museológicos, etc.) y en los instrumentos de planificación de la Administración (planes estratégicos, planes de calidad, etc.).

Con el Código de deontología, y en lo que no contradiga a la legislación vigente, el museo y las Administraciones gestoras autorregularán sus actuaciones relativas a las adquisiciones para las colecciones de museos. Con la adopción de la Ley de propiedad intelectual, el museo y la Administración gestora contribuirán, no sólo al cumplimiento de la legislación vigente, sino a la defensa de los derechos de propiedad intelectual. En la conciliación de estos derechos con el interés público radicará la fundamental aportación que se espera de los profesionales de los museos en el debate.

\section{Entidades autorizadas para la gestión de los derechos} de propiedad intelectual

$>$ Sociedad General de Autores y Editores (SGAE)

Web: www.sgae.es

> Centro Español de Derechos Reprográficos (CEDRO)

Web: wnw.cedro.org

Correo-e.: cedro@cedro.org

> Asociación de Gestión de Derechos Intelectuales (AGEDI)

Web: www.agedi.es

Correo-.: agedi@agedi.es

> Artistas Intérpretes o Ejecutantes, Sociedad de Gestión de España (AIE)

Web: uww.aie.es

Correo-e.: aie@aie.es

> Visual, Entidad de Gestión de Artistas Plásticos (VEGAP)

Web: www.egeda.es

Correo-e.: correo@egeda.es

$>$ Entidad de Gestión de Derechos de los Productores Audiovisuales (EGEDA)

Web: www.egeda.es

Correo-e.: correo@egeda.es

> Artistas Intérpretes, Sociedad de Gestión (AISGE)

Web: unw.aisge.es

Correo-e.: correo@aisge.es

> Asociación Derechos de Autor de Medios Audiovisuales (DAMA)

Web: unw.damautor.es

Correo-e.: dama@damautor.es 